\title{
O Mercado de Animais de Carga no Centro-Sul do Brasil Imperial: Novas Evidências ${ }^{\star}$
}

\author{
- Carlos Eduardo Suprinyak*
}

\begin{abstract}
RESUMO
Utilizando a inexplorada herança documental de duas unidades fiscais da província de São Paulo, o registro de Rio Negro e a barreira de Itapetininga, este trabalho analisa a estrutura do sistema de comercialização de animais de carga - muares e cavalares - estabelecido entre as regiões sul e centro-sul do Brasil imperial. A análise cobre o período 1830-1869 e abrange diversos aspectos. Inicialmente, apresentamos as séries de volumes negociados compiladas, colocando-as em perspectiva com outras evidências estatísticas disponíveis. Passamos, então, a nos ocupar com a estrutura das tropas negociadas e com a distribuição de sua propriedade, atentando para a participação relativa de cada espécie de animal e para os níveis de concentração presentes no negócio. Finalmente, analisamos de forma sucinta os padrões de distribuição espacial das atividades relacionadas ao comércio de tropas, assim como as inter-relações entre os partícipes e as diversas possibilidades de inserção associadas a este complexo sistema de abastecimento.
\end{abstract}

\section{Palavras-Chave}

comércio de tropas; mercado interno; registro do Rio Negro; barreira de Itapetininga; bestas muares

\begin{abstract}
Using the unexplored documental inheritage from two of São Paulo's province tax outposts, Rio Negro and Itapetininga, this work analyses the structure of the commercializing system for cargo animals - mules and horses - established between imperial Brazil's southern and south-central regions. The analysis covers the period from I 830 to 1869 and captures several aspects. Initially, we present the statistical series compiled with respect to negotiated volumes, putting them in perspective with other available statistical evidences. We then proceed by studying the negotiated herds' structure and their property distribution, carefully examining the share of both animal species in the whole market and the concentration levels verified in the business. Finally, we briefly examine the patterns of spatial distribution for the business correlated activities, as well as the interrelations among participants and the different possible ways of integration in this complex system.
\end{abstract}

\section{KEYWORDS}

market for cattle herds; domestic market; Rio Negro tax outpost; Itapetininga tax outpost; cargo mules

\author{
JEL CLASSIFICATION \\ N56; N76; N96
}

\footnotetext{
+ Este artigo apresenta de forma sintética os resultados alcançados em pesquisa mais ampla. Leitores interessados em uma exposição mais detalhada dos diversos temas nele abordados poderão encontrá-la em SUPRINYAK (2006). A pesquisa que deu origem ao presente artigo recebeu o auxílio da CAPES e do CNPq.

* Mestre em História Econômica pela Unesp/Ar e doutorando em Economia pelo Cedeplar/UFMG. Endereço para contato: R. Alfredo Vieira Barcelos, 808/II, Jd. das Américas, CEP: 8I530-560 - Curitiba - PR. E-mail: suprinyak@ cedeplar.ufmg.br .

(Recebido em março de 2007. Aceito para publicação em outubro de 2007).
} 


\section{INTRODUÇÃO}

O Brasil do século 19 moveu-se no lombo de bestas. Após sua satisfatória introdução na estrutura econômica brasileira durante o período colonial, os muares tornaram-se o meio de transporte por excelência das regiões não-litorâneas do Brasil imperial. As culturas do café e da cana-de-açúcar, centros dinâmicos da economia brasileira no período, dependeram funcionalmente dos serviços das tropas de mulas, tanto para o escoamento de sua produção quanto para o abastecimento regional com gêneros de outras localidades. Como afirmava Caio Prado Jr., sem as bestas de carga o Brasil teria andado ainda mais lentamente do que de fato andou.

A necessidade de um fluxo constante de abastecimento de animais nas regióes produtoras de gêneros de exportação trouxe problemas logísticos prementes para a economia imperial. Criadas majoritariamente na região sul do território brasileiro, ${ }^{1}$ as bestas muares percorriam um longo e tortuoso caminho até chegar aos locais onde eram demandadas - em especial as províncias de São Paulo e Minas Gerais. ${ }^{2}$ Visando facilitar a condução dos animais, foi aberta uma rota - o Caminho das Tropas - ligando as regiôes sul e centro-sul do território. Ao longo deste caminho, instituiu-se uma estrutura fiscal encarregada de recolher os tributos que incidiam sobre a entrada de animais soltos (i.e., sem carga) na província de São Paulo. Estas unidades fiscais, além de arrecadar vultosas quantias para os cofres provinciais, deram origem a uma extensa e rica herança documental. ${ }^{3}$

O objetivo do presente artigo é explorar esta documentação elaborada por registros e barreiras imperiais, visando compreender com maior clareza e precisão a estrutura econômica erigida em torno da atividade de abastecimento de animais de carga instituída entre as regiões sul e centro-sul - sem dúvida um dos nexos mais relevantes do mercado interno brasileiro durante o século 19. Na seção 2, é descrito de forma sucinta o corpo documental utilizado na pesquisa. Em seguida, a seção 3 apresenta uma série estatística do volume de animais negociados entre 1830 e 1869, discutindo suas flutuações e colocando-a em perspectiva com outras evidências quantitativas disponíveis para o período. A seção 4 inicia a discussão da estrutura do mercado, por meio de informações compiladas acerca do tamanho e da composição das tropas,

1 A consolidação da região sul como pólo ofertante de animais de carga deve-se, por um lado, à adequação geográfica das planícies platinas para a pecuária muar, e por outro, ao desenvolvimento prévio desta atividade na região durante o século 17 , visando suprir a demanda por animais de carga oriunda das minas de prata de Potosí. Veja-se, a respeito, Ellis Jr. (1979, p. 85-87).

2 Após o declínio da atividade mineradora no Brasil, os principais mercados consumidores dos animais de carga do sul foram as lavouras de cana-de-açúcar e café no centro-sul, assim como a comercialização interna, nesta região, de gêneros locais e importados. Vide, entre outros, Prado Jr. (2001, p. 208), Calógeras (1945, p. 1672), Petrone (1976, p. 95-98), Carrara (1997, p. 170-184), Rodarte e Godoy (2005) e Restitutti e Suprinyak (2006).

3 Sobre a abertura do Caminho das Tropas, ver Hameister (2002) e Moreira (1975); sobre a estrutura fiscal de arrecadação dos direitos sobre animais, ver Tessitore (1995), Goulart (1961) e Moreira (1975). 
assim como sua distribuição de propriedade e o grau de concentração no mercado. Na seção 5, é analisada a dispersão geográfica das diversas ocupações relacionadas ao comércio de animais, juntamente com informações sobre os indivíduos ali envolvidos. Algumas breves considerações finais encerram o trabalho.

\section{FONTES PRIMÁRIAS}

A partir da criação do registro do Rio Negro em $1830,{ }^{4}$ localizado na fronteira sul da província de São Paulo, a cobrança dos direitos sobre animais soltos - principal tributo a gravar a entrada de animais de carga destinados à comercialização - passou a ser ali realizada. Tal foi o caso até as vésperas da emancipação política do Paraná. Como o registro localizava-se em território reclamado pelos paranaenses, a província de São Paulo apressou-se em promulgar lei que extinguia a cobrança dos direitos sobre animais, ao mesmo tempo em que facultava ao presidente da província o direito de instituir uma taxa de barreira em seu lugar, com as mesmas características dos antigos direitos. Esta taxa foi instituída em 1852, e sua cobrança alocada à barreira de Itapetininga no início de 1854. As guias para cobrança foram ali emitidas pelos 15 anos seguintes, retornando na década de 1870 à barreira de Itararé, no momento em que o mercado de animais de carga começava a se desestruturar devido ao avanço das ferrovias. A herança documental legada pelo registro de Rio Negro e pela barreira de Itapetininga servirá de base para a análise a ser empreendida neste artigo.

A documentação das unidades fiscais é bastante extensa, completa e rica em informaçôes. ${ }^{5}$ Além de correspondências e escriturações contábeis, é composta por seis tipos básicos de documentos: livros da barreira correspondente e de suas agências, nos quais são registradas as passagens de animais carregados com gêneros, que pagam apenas a correspondente taxa de barreira; livros de direitos pagos à vista, que registram os direitos sobre tropas não destinadas à feira de Sorocaba ou cujo valor dos tributos devidos não exceda 50\$000, casos em que os direitos eram recolhidos no próprio local da

4 Após a Reforma Orçamentária de 1832, direitos de entrada e taxas de barreira passam a fazer parte da receita fiscal das províncias, que se mostraram desde cedo muito zelosas com sua arrecadação (Tessitore, 1995, p. 144). O local onde foi instituído o registro do Rio Negro mostrou-se especialmente adequado para estes propósitos por localizar-se logo na saída da Estrada da Mata - único caminho disponível para atravessar as densas matas dos "sertões lajeanos" - e também por constituir um dos únicos pontos favoráveis à travessia das tropas pelo rio homônimo. $\mathrm{O}$ alto valor dos direitos cobrados sobre animais soltos sempre constituiu grande incentivo para tentativas de evasão fiscal e descaminho de tropas, práticas que induziram as autoridades provinciais a continuamente reformular a estrutura de arrecadação. A criação do registro do Rio Negro no início da década de 1830 e de Xapecó (destinado a controlar o afluxo de tropas pelo caminho alternativo Missões-Palmas) a meados do século são exemplos disto (LAVALLE, 1974, p. 26; MOREIRA, 1975, passim). Não obstante, é notório que a evasão fiscal configurou um problema constante durante todo o período em análise, qualificando desta forma as informaçôes obtidas por meio dos registros oficiais.

5 Estes documentos encontram-se no Arquivo Público do Estado de São Paulo, sob o título "Livros de Barreiras - Rio Negro" e "Livros de Barreiras - Itapetininga". 
barreira; livros de termos de fiança das tropas guiadas, que reproduzem os documentos de fiança das tropas conduzidas até a feira de Sorocaba; ${ }^{6}$ segundas vias das guias emitidas para pagamento dos direitos em Sorocaba; mapas dos direitos pagos à vista $\mathrm{e}$ das tropas guiadas, que representam de forma reduzida e sistemática a movimentação das tropas nestas duas modalidades de recolhimento dos direitos. Estes documentos estão disponíveis, com falhas ocasionais, para todo o período 1830-1869.

A documentação referente à condução de animais soltos pode ser dividida em dois grupos, de acordo com a modalidade de recolhimento dos direitos: tropas guiadas ou direitos pagos à vista. No primeiro grupo, temos as tropas cujo destino era Sorocaba, ${ }^{7}$ onde eram recolhidos os direitos; já no segundo, registravam-se animais a serem comercializados, muito provavelmente, na própria região dos Campos Gerais, ao sul de Sorocaba. ${ }^{8}$ Neste trabalho, optou-se por utilizar apenas as informações relativas às tropas guiadas, isto é, aos animais com destino a Sorocaba, por duas razões: em primeiro lugar, os registros de direitos pagos à vista indicavam um padrão sazonal diverso daquele apresentado pelas tropas guiadas, com uma distribuição mais uniforme do fluxo ao longo do ano - tendo em mente que estes animais estavam, na hipótese mais provável, relacionados a um comércio local de menores proporções, sua inclusão na série acabaria por oferecer um retrato distorcido do fluxo de animais entre o sul e os mercados paulistas; além disto, a exclusão dos direitos pagos à vista na construção da série permitirá uma confrontação mais direta entre esta e outras estimativas disponíveis, como a de Lavalle (1974), que adotam a mesma metodologia na seleção dos dados.

Conforme dito acima, a documentação de passagem das tropas guiadas é bastante rica em informações. Nela, encontramos os seguintes dados, registrados de forma satisfatoriamente uniforme: data da passagem; quantidade de animais conduzidos de cada espécie (bestas muares, cavalos e éguas); valor recolhido em direitos; nomes do

6 Devido ao alto valor dos tributos e à dificuldade em transportar grandes quantidades de moeda a longas distâncias, o pagamento dos direitos era comumente efetuado em Sorocaba, quando da negociação da tropa. Desta forma, requeria-se a apresentação de um fiador residente na localidade do registro para liberar a passagem da tropa. Este fiador seria o responsável pelo pagamento dos direitos em caso de descaminho da tropa.

7 Dentre as feiras para comercialização de animais organizadas no sul da província de São Paulo, a mais próspera era realizada em Sorocaba, local do registro encarregado de fiscalizar as guias fiscais emitidas subseqüentemente em Curitiba, Rio Negro e Itapetininga. Nos campos dos arredores de Sorocaba, durante os meses de abril e maio de cada ano, os negociantes de animais mantinham suas tropas invernadas à espera dos compradores das províncias mais ao norte. Muito embora alguns negociantes conduzissem suas tropas diretamente até os compradores, em geral as tropas eram negociadas e trocavam de mãos em Sorocaba. Cf. Deffontaines (1945), Almeida (1945), Petrone (1976) e Baddini (2000).

8 Oficialmente, a diferenciação entre direitos pagos à vista ou por meio de guias estava relacionada ao valor devido: até 50\$000, pagava-se à vista; acima disto, emitia-se a guia. Entretanto, há indícios de que tropas maiores, cujos direitos excediam 50\$000, ainda assim pagavam o tributo à vista quando não tinham como destino a feira de Sorocaba. Além disto, a existência de um padrão de sazonalidade nas passagens bastante diverso entre as duas modalidades parece corroborar a idéia de que há uma diferença mais essencial entre suas naturezas. 
proprietário, do condutor e do fiador da tropa; locais de origem do condutor e do fiador; local onde a tropa era invernada. A análise apresentada no restante do artigo baseia-se neste conjunto de informações recolhido durante as quatro décadas de atuação das unidades fiscais de Rio Negro e Itapetininga, entre 1830 e 1869.

\section{VOLUMES NEGOCLADOS}

Alguns esforços de mensuração do comércio de animais no eixo sul-sudeste já foram realizados anteriormente, como por exemplo, os trabalhos de Almeida (1945) e Petrone (1976). Entretanto, de um ponto de vista quantitativo, os trabalhos mais relevantes na área são os de Lavalle (1974) e Klein (1989). Este último construiu uma série do volume de muares negociados com base nos livros do registro do Novo Imposto sobre Animais em Sorocaba - um tributo de menor monta que os direitos, cobrado diretamente em Sorocaba. Sua abrangente série cobre o período 1825-1880, porém registra apenas a movimentação de muares, não compilando informações sobre cavalares. Retomaremos a análise da série de Klein mais adiante nesta seção.

A série de Lavalle, por outro lado, está mais próxima de nossa abordagem. Surpreendentemente pouco conhecido até o momento, seu trabalho utiliza a documentação de Rio Negro para compilar uma estimativa do volume de muares e cavalares conduzidos no período 1830-1854. Não obstante, Lavalle não conseguiu recuperar as informações relativas aos dois anos iniciais e aos seis anos finais do período; assim, sua série retrata, efetivamente, a movimentação de animais em Rio Negro entre 1832 e 1848 (LAVALLE, 1974, p. 125-149).

Por meio da documentação das unidades fiscais, foi possível compilar uma série do volume de animais negociados durante todo o período de atuação da barreira de Itapetininga (1854-1869), além de completar quase todas as lacunas da série de Lavalle. Os documentos originais são periodizados em anos financeiros, que se iniciam em $1^{\circ}$ de julho de um determinado ano e terminam em 30 de junho do ano seguinte. Optamos por preservar este padrão de apresentação. Desta forma, a série que apresentamos cobre todo o período entre os anos financeiros de 1830/1831 e 1868/1869, com uma única falha: os dois últimos trimestres do ano financeiro 1852/1853. Na elaboração da série, recorremos aos mapas de tropas guiadas, utilizando os termos de fiança para complementar, sem prejuízo, as informações nos momentos em que os mapas falham. A série completa do volume de animais conduzidos pelas unidades fiscais de Rio Negro e Itapetininga é apresentada na Tabela 1. 
TABELA 1 - VOLUME DE ANIMAIS CONDUZIDOS ANUALMENTE PELO REGISTRO DE RIO NEGRO E PELA BARREIRA DE ITAPETININGA, 1830/1831 - 1868/1869

\begin{tabular}{|c|c|c|c|c|}
\hline Ano Financeiro & Muares & Cavalos & Éguas & Total \\
\hline 1830/1831 & 10.290 & 8.068 & 6.604 & 24.962 \\
\hline $1831 / 1832$ & 10.159 & 8.130 & 3.263 & 21.552 \\
\hline $1832 / 1833$ & 17.011 & 10.987 & 4.101 & 32.099 \\
\hline $1833 / 1834$ & 15.267 & 9.845 & 2.965 & 28.077 \\
\hline $1834 / 1835$ & 19.836 & 13.601 & 5.690 & 39.127 \\
\hline $1835 / 1836$ & 38.326 & 12.338 & 5.696 & 56.360 \\
\hline $1836 / 1837$ & 46.597 & 14.533 & 7.991 & 69.121 \\
\hline $1837 / 1838$ & 28.847 & 13.439 & 7.263 & 49.549 \\
\hline $1838 / 1839$ & 18.013 & 6.677 & 3.983 & 28.673 \\
\hline $1839 / 1840$ & 24.984 & 2.879 & 2.194 & 30.057 \\
\hline $1840 / 1841$ & 29.027 & 4.686 & 2.870 & 36.583 \\
\hline $1841 / 1842$ & 35.102 & 3.722 & 1.788 & 40.612 \\
\hline $1842 / 1843$ & 36.256 & 2.920 & 694 & 39.870 \\
\hline $1843 / 1844$ & 31.924 & 4.251 & 747 & 36.922 \\
\hline $1844 / 1845$ & 33.995 & 8.265 & 839 & 43.099 \\
\hline $1845 / 1846$ & 25.457 & 3.030 & 480 & 28.967 \\
\hline $1846 / 1847$ & 27.546 & 2.166 & 551 & 30.263 \\
\hline $1847 / 1848$ & 38.207 & 1.984 & 737 & 40.928 \\
\hline $1848 / 1849$ & 38.607 & 3.091 & 774 & 42.472 \\
\hline $1849 / 1850$ & 22.223 & 3.839 & 570 & 26.632 \\
\hline $1850 / 1851$ & 24.632 & 4.399 & 489 & 29.520 \\
\hline $1851 / 1852$ & 31.972 & 6.678 & 891 & 39.541 \\
\hline $1852 / 1853^{(\mathrm{a})}$ & $(18.589)$ & $(2.179)$ & (148) & (20.916) \\
\hline $1853 / 1854$ & 43.325 & 4.852 & 291 & 48.468 \\
\hline $1854 / 1855$ & 51.102 & 8.213 & 251 & 59.566 \\
\hline $1855 / 1856$ & 56.645 & 7.808 & 122 & 64.575 \\
\hline $1856 / 1857$ & 61.097 & 9.753 & 147 & 70.997 \\
\hline $1857 / 1858$ & 32.549 & 9.835 & 278 & 42.662 \\
\hline $1858 / 1859$ & 50.184 & 7.865 & 516 & 58.565 \\
\hline $1859 / 1860$ & 48.720 & 6.006 & 245 & 54.971 \\
\hline $1860 / 1861$ & 57.043 & 7.021 & 192 & 64.256 \\
\hline $186118 / 62$ & 54.001 & 6.980 & 343 & 61.324 \\
\hline $1862 / 1863$ & 19.986 & 4.939 & 330 & 25.255 \\
\hline $1863 / 1864$ & 28.285 & 4.943 & 128 & 33.356 \\
\hline $1864 / 1865$ & 28.380 & 4.845 & 270 & 33.495 \\
\hline $1865 / 1866$ & 22.254 & 2.201 & 54 & 24.509 \\
\hline $1866 / 1867$ & 29.790 & 3.162 & 64 & 33.016 \\
\hline $1867 / 1868$ & 40.464 & 3.807 & 98 & 44.369 \\
\hline $1868 / 1869$ & 50.402 & 2.446 & 75 & 52.923 \\
\hline
\end{tabular}

Fonte: Arquivo Público de São Paulo. Série Livros de Barreiras, Rio Negro e Itapetininga.

Nota: (a) Os números compilados para o ano financeiro 1852/1853 incluem apenas os negócios realizados até novembro de 1852. 
Embora o registro do Rio Negro e a barreira de Itapetininga estivessem localizados em pontos razoavelmente distantes no espaço - grosso modo, tendo a província do Paraná entre eles -, ambos dedicaram-se ao registro das tropas sujeitas ao pagamento dos direitos sobre animais soltos. Conquanto seja de se esperar certa diferença no fluxo de animais conduzidos por cada uma das estações, parece razoável supor que ambas estivessem empenhadas na mensuração de um mesmo fenômeno. Desta forma, a série de Itapetininga, quando agregada à série proposta por Lavalle com base nos livros do registro do Rio Negro, fornece um panorama satisfatoriamente homogêneo acerca da movimentação de tropas na entrada da província de São Paulo.

Observando os dados, percebemos que a década de 1850 trouxe um deslocamento marcante no nível de comercialização de muares. O ponto máximo da série de Rio Negro corresponde aos níveis mais baixos de passagem de tropas durante os oito primeiros anos de operação da barreira de Itapetininga - exceção feita ao ano financeiro de 1857/1858. Infelizmente, não possuímos informações completas sobre o ano financeiro de 1852/1853, importante por ter sido o último ano completo antes da entrada em funcionamento da barreira de Itapetininga. Marcando a transição entre as unidades fiscais, o ano 1853/1854 é composto por registros tanto de Rio Negro quanto de Itapetininga, no primeiro e segundo semestres, respectivamente. Desta forma, a elevação marcante no volume de animais conduzidos neste ano pode estar relacionada à transferência no local do registro - mais especificamente, ao ingresso de bestas por estradas que ligavam a região das Missões diretamente a Palmas, desviando o registro do Rio Negro.

O Gráfico 1 exibe de forma mais clara a evolução e as flutuações ocorridas no mercado de animais. Durante o período coberto pela documentação de Rio Negro, o mercado de muares sofreu uma severa crise, deflagrada no ano financeiro de 1836/1837. Lavalle (1974, p. 118) entende que esta tenha sido uma crise de demanda, associada a um período de dificuldades no cenário internacional que se refletiu sobre o setor agrário-exportador brasileiro, principal responsável pela demanda por muares. Por outro lado, Lavalle afirma que as duas quebras verificadas no comércio de bestas ao longo da década de 1840 estariam relacionadas aos distúrbios ocasionados pela Revolução Farroupilha e suas conseqüências ulteriores sobre a economia da província do Rio Grande de São Pedro - configurando-se, desta forma, como crises de oferta.

Os anos de atuação da barreira de Itapetininga corresponderam ao período áureo do negócio de animais. O ápice no volume de muares conduzidos ocorreu no ano de 1856/1857, quando mais de 60 mil bestas passaram pela barreira. ${ }^{9}$ Seguiu-se, então,

9 Petrone (1976, p. 29) estima que, já na década de 1830, o preço de uma besta em Sorocaba oscilava entre 40 e 60 mil-réis. Os registros contábeis de David dos Santos Pacheco, referentes ao período 18571873 , indicam preços de venda em Sorocaba com uma amplitude de variação bastante elevada, entre $32 \$ 000$ e $82 \$ 000$. Tomando $50 \$ 000$ como valor médio aproximado, uma tropa de 700 animais, nada 
uma queda abrupta no ano seguinte, sem dúvida relacionada à grave crise econômica que atingiu toda a nação, deflagrada por severos distúrbios nos mercados internacionais de commodities. ${ }^{10}$ Contudo, o comércio retornou posteriormente a altos patamares, seguindo assim até princípios da década de 1860. A partir de 1862/1863, nova crise, de enormes proporções, atingiu o mercado, ${ }^{11}$ reduzindo o volume conduzido anualmente a menos da metade. A recuperação plena viria apenas ao final da década, quando o mercado retomou os níveis do início do decênio.

Os padrões de evolução apresentados pelo mercado de cavalos são bastante distintos. Neste caso, o apogeu do negócio ocorreu durante a década de 1830, ainda no início do período em análise - note-se que no início da série os volumes de cavalos e muares negociados encontravam-se muito próximos. Após a crise desencadeada em 1836/1837, o mercado de cavalos não se recuperou plenamente até meados da década de 1850 , quando finalmente se verificou uma intensificação no comércio deste rebanho, acompanhando a ascensão do mercado de muares. Entretanto, o volume negociado não chegou sequer a igualar os níveis atingidos durante a década de 1830. A partir de então, o mercado de cavalos entrou em declínio suave, porém constante, até o fím do período.

incomum, seria negociada por aproximadamente 35 contos de réis - capital vultoso, posto que o valor médio de um escravo adulto na região sul era de um conto e meio, neste período (WESTPHALEN, 1995 , p. 60-76). Por outro lado, os inventários post-mortem da comarca de Lages estudados por Nilsen Borges (2005, p. 95) indicam que uma besta mansa era ali cotada a 25 mil-réis, a meados do século 19. A diferença entre estes valores indica a lucratividade potencial associada ao negócio.

10 Esta crise global resultou da conjunção de uma série de fatores, tais como quebras nos mercados internacionais de cereais e algodão associadas aos desdobramentos da Guerra da Criméia e instabilidades nos mercados de valores mobiliários britânico e norte-americano ocasionadas pela falência da Ohio Life Insurance and Trust Company (VILLELA, 2000, p. 244). Encontram-se freqüientes menções a esta crise nacional generalizada ocorrida em fins da década de 1850 nos Relatórios dos presidentes da província do Paraná, como no relatório de 15 de fevereiro de 1866, no qual o então presidente André Augusto de Pádua Fleury se refere às "crises porque tem passado o paiz desde 1857" (p. 53).

11 Ao contrário de 1857, esta crise ocorrida nos primeiros anos da década de 1860 parece estar relacionada essencialmente a distúrbios domésticos. Villela (2000, p. 251-252) afirma que, durante os meses finais de 1862, a praça do Rio de Janeiro sofria uma severa crise de liquidez, deflagrada pela canalização de recursos para o financiamento da expansão algodoeira no Maranhão que buscava suprir os mercados não atendidos pela produção norte-americana durante o período da Guerra Civil. Esta crise de liquidez prolongou-se pelos dois anos seguintes, criando pressóes insustentáveis sobre o sistema bancário - enrijecido pela promulgação da Lei dos Entraves em 1860 - que culminariam em falências massivas ao final de 1864. A diminuição abrupta dos negócios em Sorocaba não passou despercebida pelas autoridades da província do Paraná, preocupadas como estavam com a renda proporcionada pela arrecadação dos direitos sobre animais. O presidente da província justifica a queda ocorrida na receita provincial no ano financeiro 1862/63 por meio da "crise havida o anno passado na feira de Sorocaba, que desanimou os negociantes de animaes..."(Relatório do Presidente da Provincia do Paraná, 15 de fevereiro de 1863, p. 29). 


\section{GRÁFICO 1 - VOLUME DE ANIMAIS CONDUZIDOS PELAS ESTAÇÕES DE RIO NEGRO E ITAPETININGA, 1830/31 - 1868/69}

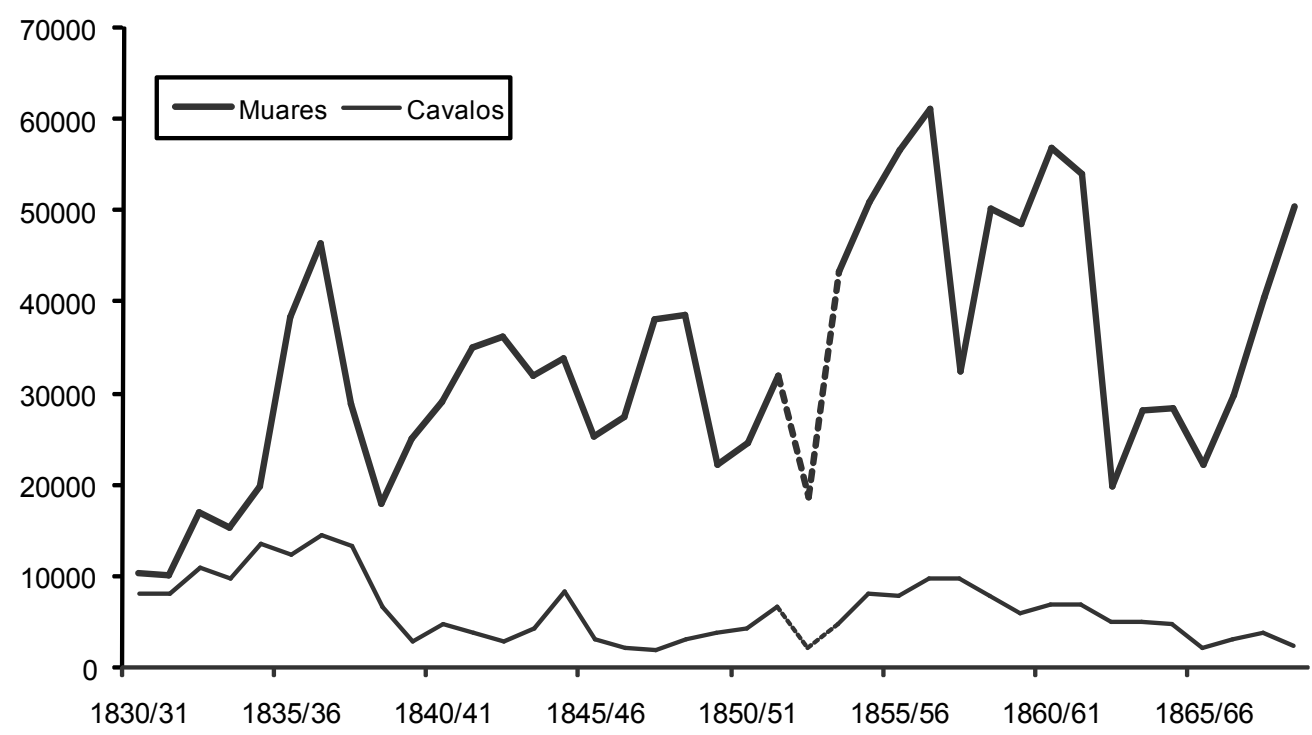

Fonte: Arquivo Público de São Paulo, Série Livros de Barreiras, Rio Negro e Itapetininga.

Nota: O segmento pontilhado indica o ano financeiro de 1852/53, cujos registros de passagem relativos aos dois últimos trimestres não foram localizados.

Exceção feita aos primeiros anos da série, as negociações com cavalos alcançaram números substancialmente inferiores àqueles registrados no mercado de muares. Progressivamente, ao longo do período imperial, os muares assumiram uma posição de predominância incontestável no total das tropas conduzidas, obscurecendo as negociações com cavalares. Em registros públicos da época, ocorreram com pouca freqüência menções específicas ao comércio de cavalos, dificultando a identificação dos fatores que determinaram o comportamento deste mercado em particular. A existência de inúmeros negociantes que atuavam simultaneamente em ambos os mercados torna ainda mais difícil uma análise do mercado de cavalos tomado isoladamente. De qualquer forma, a preferência das províncias do centro-sul era pelos muares, mais adequados ao transporte de cargas pelo relevo acidentado da região do que as espécies cavalares existentes no Brasil. ${ }^{12}$ Assim, é possível que o maior volume de cavalos conduzidos durante a década de 1830 destinava-se a suprir a demanda por cavalares dos próprios Campos Gerais, região predominantemente plana em que estes animais eram bastante utilizados na pecuária bovina. Com a transferência do local do registro em 1853, este fluxo deixou de ser captado, sugerindo uma possível explicação para a relativa apatia do mercado de cavalos durante o ápice do comércio de muares. Por 12 Cf. Prado Jr. (2001, p. 208) e Calógeras (1945, p. 1672). 
outro lado, o declínio constante no volume de éguas conduzidas está provavelmente relacionado à própria expansão do mercado de muares - dada a necessidade de éguas para a procriação de bestas, naturalmente os pecuaristas do sul relutariam em se desfazer de suas matrizes reprodutoras à medida que a demanda pelas crias aumentasse.

A sazonalidade da passagem de tropas de muares apresenta um padrão diverso nos dois momentos. O pico das movimentações em Rio Negro dava-se nos meses de outubro e novembro de cada ano. Situado na fronteira meridional da quinta comarca da província de São Paulo, passavam pelo registro as tropas recém-saídas da Estrada da Mata, que, antes de completar sua viagem até Sorocaba, necessitavam de um período de repouso e engorda em uma estação de invernagem dos Campos Gerais. Por outro lado, os registros de passagem em Itapetininga refletem a movimentação das tropas que já estavam prontas para comercialização, rumo a Sorocaba. Desta forma, verificase uma defasagem de alguns meses entre as movimentações nas duas estações fiscais, o pico em Itapetininga ocorrendo nos meses de abril e maio.

Esta particular configuração temporal da passagem das tropas explica-se por uma conjunção de fatores favoráveis. A época do ano mais propícia para a condução das tropas era a estação chuvosa (iniciada em setembro, aproximadamente), dado que, neste período, a fertilidade dos pastos estava em seu ponto máximo, facilitando a alimentação e engorda dos animais. Além disto, após o fim da estação chuvosa iniciava-se o período de colheita do açúcar e do café, para cujo transporte os muares eram demandados. Em estreita correlação com estes dois fatores, a feira de Sorocaba era realizada precisamente neste período, durante o segundo trimestre de cada ano.

A série elaborada por Herbert Klein, ao cobrir sem falhas todo o período em análise, oferece um importante contraponto para a análise até aqui desenvolvida. Embora as séries tenham sido elaboradas com base nos registros de duas modalidades tributárias diversas - o Novo Imposto sobre Animais em Sorocaba, no caso da série de Klein, e os direitos sobre os animais soltos, neste trabalho -, acreditamos que um estudo conjunto das duas não deve trazer grandes dificuldades na forma de distorções dos resultados; ao menos formalmente, ambos os tributos incidiam sobre uma mesma base: os animais soltos vindos do sul com destino à feira de Sorocaba. O Gráfico 2 apresenta lado a lado a série de Sorocaba compilada por Klein, a série conjunta Rio Negro/Itapetininga apresentada acima e também uma suavização com médias móveis de três anos desta última.

Em linhas gerais, o padrão de evolução das duas séries é semelhante. Entretanto, as flutuações na série de Itapetininga são mais bruscas do que as ocorridas na série de Klein, o que se verifica de forma clara em todos os momentos de crise. A comparação entre a série Rio Negro/Itapetininga ajustada com médias móveis de três anos e a série 
de Sorocaba parece fornecer ainda mais evidências de que o fluxo de Sorocaba reflete a movimentação nas demais unidades, porém de forma suavizada. A semelhança entre estas duas séries é notável.

Esta diferença entre as flutuações pode estar relacionada à estrutura do sistema de comercialização de animais então consolidado. Ao menos no que tange aos negócios de grande porte, sua consumação envolvia diversas etapas e exigia os esforços de vários indivíduos. ${ }^{13}$ Após passar pelas unidades fiscais do sul da província, as tropas não eram necessariamente conduzidas de imediato à feira. Poderiam ser colocadas em estações de invernagem da região, onde seriam adequadamente tratadas e ficariam à espera de condições de mercado mais favoráveis. Assim, as flutuações menos intensas registradas no fluxo por Sorocaba estariam relacionadas a um controle da oferta nos mercados da cidade por parte dos negociantes de mulas através da retenção de suas tropas nos pastos de invernagem da região meridional da província.

Ao tentar explicar a crise verificada durante a década de 1860, Klein (1989, p. 356) argumenta estar ela relacionada a distúrbios de oferta ("dificuldades climáticas e de produção”) - embora não ofereça evidências em suporte a esta idéia. A dinâmica de passagem de tropas por Itapetininga aponta para outra explicação. Considerando-se que o mercado consumidor (demanda) está mais bem representado pelas movimentações de Sorocaba do que de Itapetininga, posto que Sorocaba é o locus por excelência da comercialização dos animais, seria de se esperar que uma crise de oferta, surgindo primeiramente em Itapetininga, fosse gradualmente absorvida nas movimentações de Sorocaba. Não obstante, o que se verifica no Gráfico 2 é um padrão inverso: as flutuações surgiram primeiro em Sorocaba, sendo então transmitidas, às vezes de forma brusca, para a série de Itapetininga.

Ao contrário do proposto por Klein, estas evidências parecem indicar que a crise da década de 1860 foi desencadeada primordialmente por fatores de demanda, muito provavelmente relacionados à severa crise de liquidez ocorrida na praça do Rio de Janeiro entre 1862 e $1864 .{ }^{14} \mathrm{O}$ testemunho de personagens diretamente envolvidos com a questão também corrobora esta hipótese. Reunidas por Cecília Westphalen, as correspondências pessoais do negociante de tropas David dos Santos Pacheco, futuro Barão dos Campos Gerais, contêm freqüentes reclamações quanto ao estado dos negócios na feira de Sorocaba durante o período 1858-1861:

Há grande falta de dinbeiro e todos os negócios se conservam paralizados e amortecidos. Se Vossa Mercê tiver tropa, faça muito conter por ai, pois este negócio está ruim e sem esperança de melhorar, atenden-

13 Em transações comerciais de vulto tão elevado como as descritas na nota 9, é de se esperar que haja um cuidado especial para que a operação se realize nas melhores condições possíveis.

14 Ver nota 11. 
do ao grande número de bestas e as circunstâncias dos compradores (WESTPHALEN, 1995, p. 70)

\section{GRÁFICO 2 - VOLUME DE MUARES CONDUZIDOS PELAS ESTAÇÓES DE RIO NEGRO, ITAPETININGA E SOROCABA, 1830/31 - 1868-69}

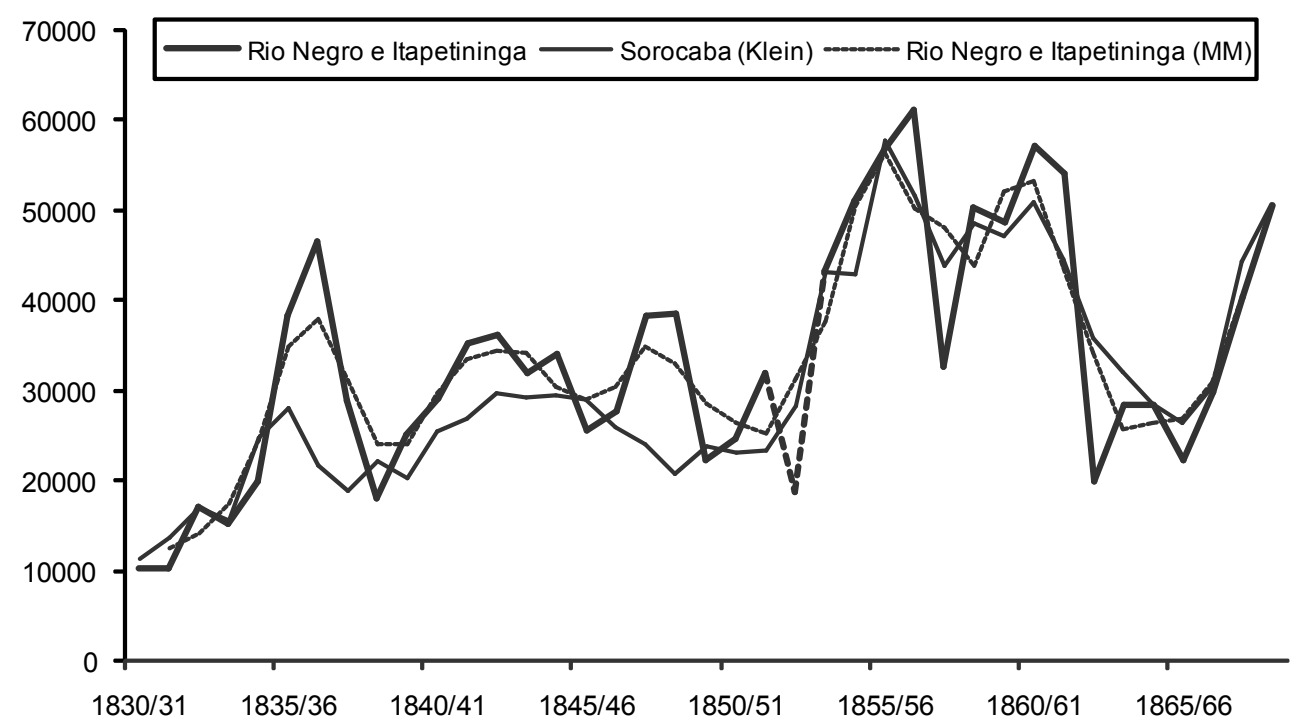

Fonte: Arquivo Público de São Paulo, Série Livros de Barreiras, Rio Negro e Itapetininga; Klein (1989, p. 370-72).

Comparando as entradas de muares na província de São Paulo com o volume de café exportado ano a ano pelo Brasil, verifica-se notável coincidência entre os padrões de evolução. As duas séries encontram-se ilustradas lado a lado no Gráfico 3. Note-se que as flutuaçôes de ambas tornam-se ainda mais semelhantes a partir da década de 1850, quando a cafeicultura consolida-se como principal setor demandante de muares. Assim, as grandes crises de 1857/1858 e 1862/1863, assim como a recuperação ao final do período, configuram-se como flutuações típicas de demanda, respondendo às condições de escoação da produção cafeeira. O mesmo ocorre com a crise da segunda metade da década de 1840, enfraquecendo sua associação aos distúrbios de longo prazo ocasionados pela Revolução Farroupilha, conforme proposto por Lavalle. Por outro lado, a crise ocorrida durante a primeira metade da década, em meio ao período mais turbulento dos conflitos no sul, não apresenta correspondência com o mercado de café, fortalecendo sua caracterização como uma crise de oferta.

A mudança de patamar ocorrida na transição entre as duas unidades também ocorre na série de Sorocaba, enfraquecendo a hipótese - mencionada anteriormente - de que 
esteja relacionada ao ingresso de tropas por rotas alternativas. É possível imaginar que, após a emancipação, tenha ocorrido intensificação na fiscalização do trânsito nas fronteiras da província de São Paulo, mais bem definidas que as do Paraná, forçando a condução dos animais até Sorocaba. Outra possibilidade é que o mercado de muares tenha sido um dos beneficiários da redistribuição do capital dos negociantes de escravos após a abolição do tráfico em 1850, dinamizando a comercialização de tropas. Por outro lado, a marcante elevação do volume de café exportado neste período indica que o crescimento do mercado de muares pode apenas refletir sua participação em um surto de prosperidade econômica de caráter mais geral. As evidências disponíveis não são suficientes para uma conclusão definitiva em favor de qualquer destas hipóteses.

\section{GRÁFICO 3 - MUARES CONDUZIDOS POR RIO NEGRO/ITAPETININGA E VOLUME DE EXPORTAÇÓES DE CAFÉ, 1830/31 - 1868-69}

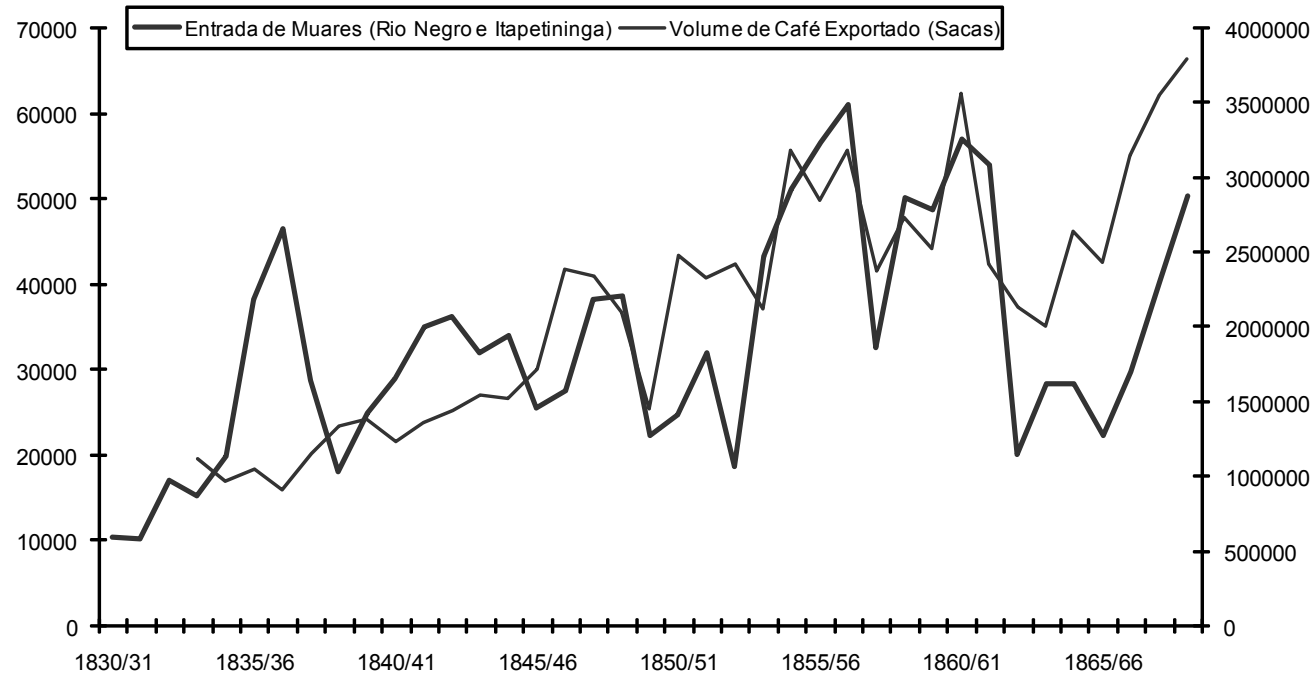

Fonte: Arquivo Público de São Paulo, Série Livros de Barreiras, Rio Negro e Itapetininga; IBGE, Anuário Estatístico do Brasil, ano V, 1939/40, p. 1374-5.

\section{COMPOSIÇÃO E DISTRIBUIÇÃO DAS TROPAS}

Nesta seção, discutiremos aspectos relacionados à estrutura das tropas conduzidas, de acordo com a participação das diversas espécies em sua composição, seus diversos tamanhos e também o grau de concentração de sua propriedade. Os dados necessários para esta apreciação não estão disponíveis para todo o período; desta forma, a análise a partir deste momento toma por base os seguintes anos financeiros: 1831/1832$1835 / 1836 ; 1840 / 1841-1841 / 1842 ; 1843 / 1844-1851 / 1852 ; 1853 / 1854-1868 / 1869$. 
A Tabela 2 apresenta uma visão agregada da composição das tropas conduzidas pelas duas unidades, de acordo com a participação dos rebanhos muar e cavalar. A predominância em ambos os momentos foi de tropas contendo animais de ambos os rebanhos (doravante denominadas tropas mistas). Houve uma diminuição da participação relativa das tropas mistas durante o período de Itapetininga, mas ainda assim elas respondem por mais de $75 \%$ do total das tropas. Esta constatação indica que a estrutura do mercado de animais de carga neste período é caracterizada por marcante interpenetração entre os dois rebanhos, muar e cavalar.

Entretanto, esta interpenetração não pode ser exagerada. Grande parte das tropas mistas é composta por um volume expressivo de animais de uma espécie e apenas uns poucos da outra. Desta forma, assemelham-se mais a uma tropa especializada em um rebanho, com a participação casual de alguns animais de espécie diversa, do que a uma tropa propriamente mista. A participação de tropas assim configuradas no total das tropas mistas também cresce na transição entre Rio Negro e Itapetininga - de uma média de aproximadamente $33 \%$ no primeiro período para $67 \%$ durante o segundo. Aliada à menor participação relativa das tropas mistas nos registros de Itapetininga, esta evidência indica um aumento da especialização entre os dois mercados - muares e cavalares - ao longo do período.

TABELA 2 - COMPOSIÇÃO DAS TROPAS CONDUZIDAS PELO REGISTRO DE
RIO NEGRO E PELA BARREIRA DE ITAPETININGA, 1830-1869

\begin{tabular}{lrrrrc}
\hline Tipo de Tropa & No Tropas & \multicolumn{1}{c}{$\%$} & No Animais & \multicolumn{1}{c}{$\%$} & Média p/ tropa \\
\hline \multicolumn{7}{c}{ Rio Negro } \\
\hline Apenas Muares & 152 & 5,19 & 34.877 & 5,22 & 229,45 \\
Muares e Cavalares & 2.724 & 93,00 & 627.284 & 93,85 & 230,28 \\
Apenas Cavalares & 53 & 1,81 & 6.261 & 0,94 & 118,13 \\
Total & 2.929 & 100,00 & 668.422 & 100,00 & 228,21 \\
\hline \multicolumn{7}{c}{ Itapetininga } \\
\hline Apenas Muares & 546 & 19,84 & 142.934 & 19,70 & 261,78 \\
Muares e Cavalares & 1.933 & 70,24 & 554.107 & 76,38 & 286,66 \\
Apenas Cavalares & 273 & 9,92 & 28.462 & 3,92 & 104,26 \\
Total & 2.752 & 100,00 & 725.503 & 100,00 & 263,63 \\
\hline
\end{tabular}

Fonte: Arquivo Público de São Paulo. Série Livros de Barreiras, Rio Negro e Itapetininga.

Embora fosse possível encontrar tropas dos mais diversos tamanhos em todas as categorias, as tropas mistas apresentavam tamanho médio superior às tropas especializadas em ambos os períodos, com maior superioridade em Itapetininga. Dentro das tropas mistas, predominavam os muares por ampla margem. Entre as tropas especializadas, 
as tropas de muares possuíam tamanho médio muito superior às tropas de cavalares. A participação relativa das tropas de muares também era bastante superior a das tropas de cavalares. Tudo isto, é claro, refletia-se no amplo predomínio dos muares no total de animais conduzidos.

Ao analisar a distribuição das tropas de acordo com seu tamanho, optamos por dividi-las em quatro faixas de tamanho. Os resultados obtidos encontram-se na Tabela 3. Eles indicam a existência de concentração no mercado: tropas pequenas, embora representassem uma parcela significativa do total das passagens, respondiam por pequena parcela dos animais conduzidos, o inverso ocorrendo com as tropas grandes. A este respeito, o espectro de variação também é bastante ilustrativo. Em Rio Negro, as tropas variaram entre um tamanho mínimo de 21 e máximo de 2.541 animais, enquanto em Itapetininga os limites registrados foram 21 e 1.500, respectivamente. Confrontando a distribuição em Rio Negro e Itapetininga, identificamos aumento na participação relativa da classe de tropas grandes, tanto no total de tropas quanto de animais, com redução nas participações de todas as outras três classes. Verificou-se aumento nos tamanhos médios das tropas de todas as classes à exceção da segunda, que permaneceu estável.

Comparando a evolução ano a ano do tamanho médio das tropas com o volume total de animais negociados, identifica-se uma relação direta entre ambos, embora não necessariamente proporcional. Esta constatação permite imaginar que uma parcela significativa das oscilações conjunturais do mercado era absorvida pelos negociantes por meio de ajustes internos em suas atividades, e não por meio da entrada e saída de novos negociantes. Em outras palavras, o mercado de animais possuía uma estrutura suficientemente concentrada para garantir aos negociantes nele inseridos um poder de mercado tal sobre suas atividades que lhes permitia adaptar-se à instável conjuntura. Quando estendemos esta análise para a amostra dividida em faixas de tamanho, os resultados são favoráveis: oscilações no mercado eram absorvidas em sua maior parte pelas tropas de maior porte - em outras palavras, os ajustes conjunturais eram realizados pelos grandes negociantes. 
TABELA 3 - DISTRIBUIÇÃO DAS TROPAS CONDUZIDAS POR RIO NEGRO E ITAPETININGA SEGUNDO FAIXAS DE TAMANHO, 1830-1869

\begin{tabular}{|c|c|c|c|c|c|}
\hline Faixa (total de animais) & $\mathrm{N}^{0}$ Tropas & $\%$ & $\mathrm{~N}^{0}$ Animais & $\%$ & Média p/ tropa \\
\hline \multicolumn{6}{|c|}{ Rio Negro } \\
\hline $1-99$ & 810 & 27,65 & 53.591 & 8,02 & 66,16 \\
\hline $100-249$ & 1.143 & 39,02 & 184.611 & 27,62 & 161,51 \\
\hline $250-499$ & 700 & 23,90 & 242.617 & 36,30 & 346,60 \\
\hline 500 ou + & 276 & 9,42 & 187.603 & 28,07 & 679,72 \\
\hline Total & 2.929 & 100,00 & 668.422 & 100,00 & 228,21 \\
\hline \multicolumn{6}{|c|}{ Itapetininga } \\
\hline $1-99$ & 742 & 26,96 & 44.683 & 6,16 & 60,22 \\
\hline $100-249$ & 955 & 34,70 & 154.239 & 21,26 & 161,51 \\
\hline $250-499$ & 607 & 22,06 & 221.364 & 30,51 & 364,69 \\
\hline 500 ou + & 448 & 16,28 & 305.217 & 42,07 & 681,29 \\
\hline Total & 2.752 & 100,00 & 725.503 & 100,00 & 263,63 \\
\hline
\end{tabular}

Fonte: Arquivo Público de São Paulo. Série Livros de Barreiras, Rio Negro e Itapetininga.

A confirmação definitiva do alto grau de concentração verificado no mercado de animais - que teria conferido aos negociantes de grande porte a possibilidade de adaptarse de forma mais eficiente à conjuntura - pode ser obtida por meio da incorporação na análise de informaçôes sobre a propriedade das tropas. Ao associar cada tropa ao seu proprietário, podemos calcular índices de Gini sobre a distribuição das tropas e animais conduzidos por cada proprietário, utilizando-os como indicadores do grau de concentração no mercado. No cálculo dos índices, cavalares e muares foram analisados conjuntamente, de forma a evitar distorções nos resultados relacionadas com a interpenetração entre os rebanhos na composição das tropas identificada acima.

Os índices de Gini calculados para Rio Negro atingiram o valor de 0,338 na distribuição da propriedade das tropas e 0,585 na distribuição da propriedade dos animais. No caso de Itapetininga, os valores são de 0,347 para tropas e 0,604 para animais. Estes coeficientes - superiores aos encontrados por Klein para o mercado de animais (KLEIN, 1989, p. 361-363) e também superiores aos coeficientes típicos de distribuição de posse de cativos no Brasil - indicam a presença de um nível significativo de concentração no mercado. A diferença entre a concentração na propriedade de tropas e animais é natural devido ao longo tempo de maturação envolvido na negociação de uma tropa. Os índices também demonstram de forma clara, sob ambos os critérios, o aumento da concentração ocorrido na transição entre Rio Negro e Itapetininga. 


\section{TABELA 4 - ÍNDICES DE GINI TRIENAIS SOBRE DISTRIBUIÇÃO DA PROPRIEDADE DAS TROPAS E ANIMAIS, TRIENNIOS SELECIONADOS}

\begin{tabular}{lcccc}
\hline Período & Gini (Tropas) & $N^{0}$ de Tropas & Gini (Animais) & No de Animais \\
\hline $1833 / 34-35 / 36$ & 0,137 & 481 & 0,471 & 123.614 \\
$1843 / 44-45 / 46$ & 0,164 & 481 & 0,484 & 108.563 \\
$1846 / 47-48 / 49$ & 0,169 & 531 & 0,514 & 113.668 \\
$1849 / 50-51 / 52$ & 0,144 & 509 & 0,509 & 95.698 \\
$1854 / 55-56 / 57$ & 0,218 & 797 & 0,532 & 195.138 \\
$1857 / 58-59 / 60$ & 0,184 & 603 & 0,519 & 156.193 \\
$1860 / 61-62 / 63$ & 0,157 & 591 & 0,517 & 152.504 \\
$1863 / 64-65 / 66$ & 0,146 & 374 & 0,556 & 91.360 \\
$1866 / 67-68 / 69$ & 0,205 & 387 & 0,543 & 130.308 \\
\hline
\end{tabular}

Fonte: Arquivo Público de São Paulo. Série Livros de Barreiras, Rio Negro e Itapetininga.

Podemos perceber de forma mais detalhada a evolução da concentração observando os índices de Gini trienais apresentados na Tabela 4. Os índices trienais são inferiores aos agregados tanto para tropas quanto para animais, porém estão proporcionalmente muito mais distantes no caso das tropas - indicando alta diluição das passagens de um mesmo negociante ao longo do tempo. Ambas as séries evoluem de forma semelhante ao longo do tempo, indicando de forma clara aumento da concentração. $\mathrm{Na}$ comparação com os volumes negociados, verifica-se que em quase todos os casos a concentração varia de forma pró-cíclica: quando o mercado está aquecido, aumenta a concentração e vice-versa. As exceções são os dois últimos triênios. Entre 1863/1864 e 1864/1865, período que sucede a grande crise do início da década, a concentração na distribuição dos animais aumenta. Esta ocorrência pode estar associada a alguma reestruturação do mercado em decorrência da crise, mais prolongada que as demais, eliminando comerciantes de menor porte e fortalecendo a posição dos grandes negociantes. A reversão ocorrida no fim da década refletiria a abertura de novas oportunidades para os pequenos associada à recuperação do mercado.

Assim, a evolução dos níveis de concentração fortalece a hipótese de que as flutuações conjunturais no mercado de animais são absorvidas em sua maior parte por negociantes de grande porte, e de que estes ajustes são realizados fundamentalmente por alterações no tamanho das tropas, e não na frequiência das passagens. 


\section{DISTRIBUIÇÃO GEOGRÁFICA E PADRÕES DE INSERÇÃO}

A documentação das unidades fiscais apresenta informações a respeito de três diferentes modalidades de participação no mercado de animais: condutores de tropas, proprietários de tropas e fiadores. Proprietários de tropas, obviamente, eram aqueles a quem pertenciam os animais, sendo responsáveis diretos pelo pagamento dos direitos devidos. Os condutores acompanhavam pessoalmente a tropa durante o percurso, desde a aquisição (normalmente no extremo sul) até o destino final, sendo responsáveis pelos cuidados com a boa manutenção dos animais. Podiam ou não ser eles próprios os proprietários das tropas; quando não o eram, trabalhavam contratados pelo proprietário, recebendo um ordenado pela tarefa. ${ }^{15}$ A apresentação de fiadores era exigência do próprio sistema de arrecadação dos direitos - como estes não eram pagos à vista no local do registro, exigia-se a assinatura de um termo de fiança por meio do qual algum destacado habitante da região responsabilizava-se pelo pagamento dos direitos em caso de inadimplência do proprietário. Conforme veremos adiante, muito embora alguns casos extremos possam indicar a ocorrência de eventuais remunerações por serviços de fiança prestados, as relações entre proprietários de tropas e fiadores pareciam estar ancoradas em relações socioeconômicas de outra natureza. Por fim, a documentação também indica, em grande parte dos casos, o local onde as tropas seriam invernadas, recompondo-se fisicamente até a chegada de momento propício para venda.

De forma a alcançar maior clareza na exposição, recorreremos a uma regionalização para analisar a distribuição geográfica das passagens. As localidades foram divididas em 11 grupos, seguindo a geografia dos atuais Estados do Rio Grande do Sul, Santa Catarina, Paraná (onde serão incluídas também as tropas conduzidas antes da emancipação), Rio de Janeiro e Minas Gerais. Devido ao grande número de localidades em domínios paulistas, dividiremos esta região em cinco sub-regiões: sul (vizinhanças do Caminho das Tropas, na região de Sorocaba e Itapetininga), centro (região da capital), oeste, litoral e vale do Paraíba. ${ }^{16}$ Por fim, classificaremos como "outras localidades" aqueles locais que não se enquadram nesta classificação geral. As Tabelas $5 \mathrm{e}$ 6 apresentam a distribuição dos condutores, fiadores e locais de invernada das tropas conduzidas por Rio Negro e Itapetininga, de acordo com esta classificação.

Os documentos discriminam os nomes dos proprietários, porém não a sua origem, o que inviabiliza uma comparação entre a distribuição geográfica de condutores e proprietários. Não obstante, a simples análise da distribuição geográfica dos con-

15 Os registros contábeis de David dos Santos Pacheco mostram que os salários pagos ao "capataz condutor” oscilavam entre $250 \$ 000$ e $300 \$ 000$ por tropa conduzida, além de vencimentos adicionais variando entre 50\$000 e 70\$000 para cada um de seus ajudantes (WESTPHALEN, 1995, p. 61-65).

16 Esta divisão segue, em linhas gerais, aquela proposta por Francisco Vidal Luna e Herbert Klein (2003). 
dutores de tropas é bastante instrutiva. Em Rio Negro, verificou-se predomínio de condutores da região do atual Estado do Paraná no total, seguidos pelos paulistas da região sul. As participações de condutores de Santa Catarina e do Rio Grande do Sul também foram significativas, com destaque para o grande tamanho médio das tropas de condutores gaúchos. Dentre as 70 localidades registradas, as três mais relevantes foram paranaenses (Castro, Lapa e Ponta Grossa), seguidas por três localidades paulistas (Sorocaba, Faxina e Itapetininga). Entre as localidades com maior freqüência de condutores, também encontramos vilas catarinenses e gaúchas, como Lages, Vacaria e Missões.

Em conexão com a própria estrutura do sistema de fianças, a distribuição dos fiadores foi marcada por predominância de regiões próximas às unidades fiscais. No caso de Rio Negro, houve predomínio absoluto de fiadores paranaenses, seguidos por paulistas da região sul - juntos, estes dois grupos responderam por quase $95 \%$ das tropas e animais conduzidos. Registrou-se 45 localidades diferentes, e as três mais relevantes foram localidades paranaenses: em primeiro lugar Rio Negro, o próprio local do registro, seguido por Lapa e Castro, localizadas nas imediaçóes. No caso dos locais de invernada, repetiu-se o mesmo padrão. Predominaram por larga margem as estações paranaenses, seguidas por aquelas do sul de São Paulo. Foram registrados 57 locais de invernada diferentes, dentre os quais se destacaram Castro, Lapa e Ponta Grossa - três localidades da região dos Campos Gerais que, juntas, foram responsáveis pela invernagem de aproximadamente $45 \%$ das tropas e animais. Além disto, uma parcela significativa das tropas (10\%) registrou apenas a indicação genérica "Campos Geraes”, reforçando ainda mais o predomínio desta região como principal centro de invernagem das tropas. 
TABELA 5 - DISTRIBUIÇÃO GEOGRÁFICA DOS CONDUTORES, FIADORES E DOS LOCAIS DE INVERNADA DAS TROPAS CONDUZIDAS POR RIO NEGRO

\begin{tabular}{|c|c|c|c|c|c|}
\hline \multicolumn{6}{|c|}{ CONDUTORES } \\
\hline Região & $\mathrm{N}^{0}$ Tropas & $\%$ & $\mathrm{~N}^{0}$ Animais & $\%$ & Média p/ tropa \\
\hline Rio Grande do Sul & 69 & 6,09 & 17.340 & 7,28 & 251,30 \\
\hline Santa Catarina & 71 & 6,27 & 12.768 & 5,36 & 179,83 \\
\hline Paraná & 682 & 60,19 & 141.798 & 59,55 & 207,91 \\
\hline São Paulo & 304 & 26,83 & 63.727 & 26,76 & 209,63 \\
\hline Centro & 22 & 1,94 & 4.435 & 1,86 & 201,59 \\
\hline Oeste & 27 & 2,38 & 4.461 & 1,87 & 165,22 \\
\hline Sul & 246 & 21,71 & 50.881 & 21,37 & 206,83 \\
\hline Vale & 9 & 0,79 & 3.950 & 1,66 & 438,89 \\
\hline Minas Gerais & 1 & 0,09 & 1.135 & 0,48 & $1.135,00$ \\
\hline Rio de Janeiro & 4 & 0,35 & 925 & 0,39 & 231,25 \\
\hline Outras Localidades & 2 & 0,18 & 432 & 0,18 & 216,00 \\
\hline Total & 1133 & 100,00 & 238.125 & 100,00 & 210,17 \\
\hline \multicolumn{6}{|c|}{ FIADORES } \\
\hline Região & $\mathrm{N}^{0}$ Tropas & $\%$ & $\mathrm{~N}^{0}$ Animais & $\%$ & Média $\mathrm{p} /$ tropa \\
\hline Rio Grande do Sul & 5 & 0,44 & 1.684 & 0,71 & 336,80 \\
\hline Santa Catarina & 22 & 1,94 & 5.407 & 2,27 & 245,77 \\
\hline Paraná & 856 & 75,55 & 181.092 & 76,13 & 211,56 \\
\hline São Paulo & 247 & 21,80 & 49.225 & 20,69 & 199,29 \\
\hline Centro & 15 & 1,32 & 2.994 & 1,26 & 199,60 \\
\hline Oeste & 13 & 1,15 & 3.122 & 1,31 & 240,15 \\
\hline Sul & 212 & 18,71 & 40.982 & 17,23 & 193,31 \\
\hline Vale & 7 & 0,62 & 2.127 & 0,89 & 303,86 \\
\hline Outras Localidades & 3 & 0,26 & 470 & 0,20 & 156,67 \\
\hline Total & 1.133 & & 558.018 & 100,00 & 209,95 \\
\hline \multicolumn{6}{|c|}{ LOCAIS DE INVERNADA } \\
\hline Região & $\mathrm{N}^{0}$ Tropas & $\%$ & $\mathrm{~N}^{\circ}$ Animais & $\%$ & Média p/ tropa \\
\hline Rio Grande do Sul & 1 & 0,09 & 508 & 0,23 & 508,00 \\
\hline Santa Catarina & 3 & 0,28 & 384 & 0,17 & 128,00 \\
\hline Paraná & 753 & 69,15 & 155480 & 69,68 & 206,48 \\
\hline São Paulo & 303 & 27,82 & 59888 & 26,84 & 197,65 \\
\hline Centro & 25 & 2,30 & 4367 & 1,96 & 174,68 \\
\hline Litoral & 1 & 0,09 & 99 & 0,04 & 99,00 \\
\hline Oeste & 27 & 2,48 & 4156 & 1,86 & 153,93 \\
\hline Sul & 249 & 22,87 & 51014 & 22,86 & 204,88 \\
\hline Vale & 1 & 0,09 & 252 & 0,11 & 252,00 \\
\hline Minas Gerais & 1 & 0,09 & 84 & 0,04 & 84,00 \\
\hline Outras Localidades & 2 & 0,18 & 334 & 0,15 & 167,00 \\
\hline Feira & 26 & 2,39 & 6458 & 2,89 & 248,38 \\
\hline Total & 1089 & & 223136 & 100,00 & 204,90 \\
\hline
\end{tabular}

Fonte: Arquivo Público de São Paulo. Série Livros de Barreiras, Rio Negro e Itapetininga. 
Após a transição para Itapetininga, o quadro sofreu diversas alterações. Entre os condutores, o predomínio no total das tropas foi dos paulistas - em especial por meio dos condutores da sub-região sul, porém com participação significativa das sub-regiões oeste e centro. Em segundo lugar aparecem os condutores paranaenses. Condutores da região de Santa Catarina perderam importância relativa; por outro lado, os gaúchos conseguiram aumentar sua parcela no total, mais uma vez conduzindo tropas de alto tamanho médio. Entretanto, note-se que os paranaenses predominaram no total de animais, o que se reflete no maior tamanho médio das tropas de condutores paranaenses. Entre as mais recorrentes das 125 localidades registradas, houve equilíbrio entre paulistas e paranaenses. Sorocaba e Castro ocuparam as duas primeiras posições, seguidas por Itapetininga, Faxina, Ponta Grossa e Lapa.

Mais uma vez, os fiadores apresentaram uma distribuição concentrada em torno da região da barreira. Embora a dispersão fosse maior do que a verificada em Rio Negro, constatamos a predominância de fiadores paulistas, em especial da sub-região sul. Em um distante segundo lugar aparecem os paranaenses. Dentre as 99 localidades, a mais relevante foi Itapetininga, sozinha responsável pela fiança de mais de $30 \%$ das tropas. Embora Rio Negro sequer aparecesse entre as dez principais localidades, algumas vilas paranaenses seguiram desempenhando papel importante - caso de Castro, Ponta Grossa e Lapa. A comparação entre as estatísticas nos dois momentos atesta de forma clara a relevância do local da unidade fiscal na determinação da distribuição geográfica dos fiadores.

No que tange aos locais de invernada, ocorreu uma mudança importante. As localidades paranaenses responderam pela invernagem de pouco mais de $1 \%$ do total das tropas conduzidas - o que é compreensível, dado que a barreira de Itapetininga encontrava-se em território paulista. Entretanto, este espaço não era ocupado por estações paulistas de invernada. Pelo contrário, a maior parte das tropas (mais de $60 \%$ do total das tropas e quase $80 \%$ do total de animais) destinava-se diretamente à feira de Sorocaba - em outras palavras, seria imediatamente comercializada. Dentre as tropas não destinadas à feira, quase a totalidade rumava para estaçôes de invernada paulistas, distribuídas pelas sub-regióes sul, oeste e centro. As localidades citadas com maior freqüência foram Sorocaba e Itapetininga. 
TABELA 6 - DISTRIBUIÇÃO GEOGR ÁFICA DOS CONDUTORES, FIADORES E DOS LOCAIS DE INVERNADA DAS TROPAS CONDUZIDAS POR ITAPETININGA

\begin{tabular}{|c|c|c|c|c|c|}
\hline \multicolumn{6}{|c|}{ CONDUTORES } \\
\hline Região & $\mathrm{N}^{0}$ Tropas & $\%$ & $\mathrm{~N}^{0}$ Animais & $\%$ & Média p/ tropa \\
\hline Rio Grande do Sul & 172 & 7,76 & 69.386 & 12,43 & 403,41 \\
\hline Santa Catarina & 42 & 1,90 & 10.420 & 1,87 & 248,10 \\
\hline Paraná & 867 & 39,12 & 305.957 & 54,83 & 352,89 \\
\hline São Paulo & 1496 & 67,51 & 273.335 & 48,98 & 182,71 \\
\hline Centro & 178 & 8,03 & 32.733 & 5,87 & 183,89 \\
\hline Oeste & 389 & 17,55 & 62.742 & 11,24 & 161,29 \\
\hline Sul & 867 & 39,12 & 163.065 & 29,22 & 188,08 \\
\hline Vale & 62 & 2,80 & 14.795 & 2,65 & 238,63 \\
\hline Minas Gerais & 13 & 0,59 & 5.862 & 1,05 & 450,92 \\
\hline Rio de Janeiro & 18 & 0,81 & 3.964 & 0,71 & 220,22 \\
\hline Outras Localidades & 11 & 0,50 & 3.134 & 0,56 & 284,91 \\
\hline Não Identificados & 7 & 2,80 & 2.463 & 2,65 & 351,86 \\
\hline Total & 2.626 & 100,00 & 674.521 & 100,00 & 256,86 \\
\hline \multicolumn{6}{|c|}{ FIADORES } \\
\hline Região & $\mathrm{N}^{0}$ Tropas & $\%$ & $\mathrm{~N}^{0}$ Animais & $\%$ & Média p/ tropa \\
\hline Rio Grande do Sul & 104 & 3,97 & 45509 & 6,77 & 437,59 \\
\hline Santa Catarina & 13 & 0,50 & 4228 & 0,63 & 325,23 \\
\hline Paraná & 795 & 30,37 & 303211 & 45,08 & 381,40 \\
\hline São Paulo & 1690 & 64,55 & 314952 & 46,83 & 186,36 \\
\hline Centro & 103 & 3,93 & 18176 & 2,70 & 176,47 \\
\hline Litoral & 1 & 0,04 & 136 & 0,02 & 136,00 \\
\hline Oeste & 274 & 10,47 & 50027 & 7,44 & 182,58 \\
\hline Sul & 1282 & 48,97 & 239610 & 35,62 & 186,90 \\
\hline Vale & 30 & 1,15 & 7003 & 1,04 & 233,43 \\
\hline Minas Gerais & 3 & 0,11 & 589 & 0,09 & 196,33 \\
\hline Rio de Janeiro & 7 & 0,27 & 2245 & 0,33 & 320,71 \\
\hline Outras Localidades & 5 & 0,19 & 1312 & 0,20 & 262,40 \\
\hline Não Identificados & 1 & 0,04 & 556 & 0,08 & 556,00 \\
\hline Total & 2.618 & 100,00 & 672.602 & 100,00 & 256,91 \\
\hline \multicolumn{6}{|c|}{ LOCAIS DE INVERNADA } \\
\hline Região & $\mathrm{N}^{0}$ Tropas & $\%$ & $\mathrm{~N}^{0}$ Animais & $\%$ & Média p/ tropa \\
\hline Rio Grande do Sul & 9 & 0,34 & 1.293 & 0,19 & 143,67 \\
\hline Santa Catarina & 1 & 0,04 & 168 & 0,02 & 168,00 \\
\hline Paraná & 30 & 1,14 & 4.050 & 0,60 & 135,00 \\
\hline São Paulo & 905 & 34,38 & 146.459 & 21,64 & 161,83 \\
\hline Centro & 136 & 5,17 & 19.039 & 2,81 & 139,99 \\
\hline Oeste & 317 & 12,04 & 49.369 & 7,29 & 155,74 \\
\hline Sul & 412 & 15,65 & 70.614 & 10,43 & 171,39 \\
\hline Vale & 40 & 1,52 & 7.437 & 1,10 & 185,93 \\
\hline Minas Gerais & 7 & 0,27 & 1.963 & 0,29 & 280,43 \\
\hline Rio de Janeiro & 5 & 0,19 & 664 & 0,10 & 132,80 \\
\hline Outras Localidades & 3 & 0,11 & 292 & 0,04 & 97,33 \\
\hline Feira & 1.672 & 63,53 & 522.005 & 77,12 & 312,20 \\
\hline Total & 2.632 & 100,00 & 676.894 & 100,00 & 257,18 \\
\hline
\end{tabular}

Fonte: Arquivo Público de São Paulo. Série Livros de Barreiras, Rio Negro e Itapetininga. 
Por fim, passamos a discorrer brevemente sobre os indivíduos envolvidos nesta rede de comercialização de animais. A Tabela 7 apresenta algumas estatísticas interessantes sobre a participação de condutores, fiadores e proprietários no negócio de animais. A classe de partícipes que apresentou maior grau de concentração foi a dos fiadores. Tanto em Rio Negro quanto Itapetininga, a média de tropas e animais afiançados por cada fiador foi superior às médias de tropas e animais por condutor e proprietário. $\mathrm{O}$ número máximo de tropas e animais afiançados por um único indivíduo também foi bastante superior ao das demais ocupações - em Rio Negro, registrou-se a ocorrência de um fiador responsável isoladamente por 195 tropas e mais de 50 mil animais. Casos extremos assim indicam a existência de indivíduos altamente especializados, que talvez até mesmo percebiam remunerações pelas atividades de fiança, muito embora esta não parecesse ser a regra. A média de tropas por condutor e proprietário foi inferior a dois em ambos os momentos. Em Rio Negro, houve equilíbrio entre as médias para condutores e proprietários, porém em Itapetininga verificou-se um grau levemente mais elevado de concentração entre os proprietários.

\section{TABELA 7 - FREQÜÊNCIA DE PARTICIPAÇÃO DOS ENVOLVIDOS NO NEGÓCIO DE ANIMAIS DE CARGA}

\begin{tabular}{lccccc}
\hline Classe & Participantes & $\begin{array}{c}\text { Média de } \\
\text { tropas }\end{array}$ & $\begin{array}{c}\text { Média de } \\
\text { animais }\end{array}$ & $\begin{array}{c}\text { Máximo de } \\
\text { tropas }\end{array}$ & $\begin{array}{c}\text { Máximo de } \\
\text { animais }\end{array}$ \\
\hline Proprietários & 1.693 & 1,73 & 394,80 & 20 & 14.189 \\
Condutores & 1.691 & 1,73 & 395,28 & 16 & 5.856 \\
Fiadores & 833 & 3,52 & 802,43 & 195 & 51.526 \\
\hline \multicolumn{5}{c}{ Itapetininga } \\
\hline Proprietários & 1.494 & 1,84 & 485,60 & 21 & 10.781 \\
Condutores & 1.553 & 1,77 & 467,16 & 16 & 8.319 \\
Fiadores & 1.279 & 2,15 & 567,24 & 40 & 11.923 \\
\hline
\end{tabular}

Fonte: Arquivo Público de São Paulo. Série Livros de Barreiras, Rio Negro e Itapetininga.

Os registros permitem compreender de forma mais precisa as relações entre condutores e proprietários. Em Rio Negro, aproximadamente $80 \%$ das tropas eram conduzidas por seus proprietários. Em Itapetininga, esta parcela subia para 83\%. O tamanho médio das tropas conduzidas diretamente pelos proprietários foi significativamente inferior ao das tropas conduzidas por terceiros. Em Rio Negro, os números médios foram 299,67 animais por tropa de proprietário não-condutor e 209,67 animais por tropa de proprietário condutor; em Itapetininga, estas médias subiram para 367,48 e 239,24, respectivamente. 
Entre proprietários e condutores, quando estes não eram a mesma pessoa, predominavam relações estáveis. No caso de Rio Negro, dentre os 399 proprietários que não conduziram suas próprias tropas, 331 trabalharam com apenas um condutor. Dos 68 restantes, 44 trabalharam com dois condutores diferentes. Pela ótica dos condutores, verificamos que dentre os 401 condutores não-proprietários de Rio Negro, 326 trabalharam com apenas um proprietário, enquanto outros 52 trabalharam com dois proprietários diferentes. Nas passagens de Itapetininga a estabilidade é igualmente marcante. Dentre os 223 proprietários não-condutores, 177 empregaram apenas um condutor e outros 21 empregaram dois; em relação aos 292 condutores não-proprietários, 263 trabalharam com apenas um proprietário e 23 com dois deles. Em suma, embora haja casos extremos (um condutor trabalhando com 12 proprietários diferentes, um proprietário trabalhando com 16 condutores diferentes), em mais de $75 \%$ dos casos os condutores trabalharam com apenas um proprietário, assim como os proprietários, com apenas um condutor.

Vejamos agora com mais detalhe as relaçóes entre proprietários e fiadores. O número de fiadores registrado foi substancialmente inferior ao de proprietários, indicando predominância de fiadores que prestaram serviços a mais de um proprietário. De fato, a estabilidade das relações proprietário/fiador foi menor que a verificada entre proprietários e condutores. Dentre as 2.237 diferentes combinações entre fiador e proprietário registradas na documentação de Rio Negro, 2.093 ocorreram apenas uma única vez, outras 115 apenas duas vezes. Em Itapetininga, as passagens indicam 2.471 pares fiador/proprietário diferentes, e 2.345 destas combinações $(94,9 \%)$ ocorreram apenas uma vez. Aproximadamente $40 \%$ dos fiadores em Rio Negro e $31 \% \mathrm{em}$ Itapetininga prestaram serviços a mais de um proprietário, havendo casos extremos de fiadores associados a 60, 64 e até 173 proprietários diferentes - mais uma vez indicando a possível existência de fiadores especializados, percebendo remuneração por seus serviços. Entre os proprietários, cerca de $27 \%$ em Rio Negro e $33 \%$ em Itapetininga trabalharam com mais de um fiador - no extremo, 12 fiadores diferentes para um proprietário. Calculando índices de Gini sobre a distribuição dos fiadores, confirma-se a impressão inicial de maior concentração nesta atividade: tomando Itapetininga como parâmetro, a concentração calculada pelo total de animais entre os fiadores alcançou 0,624 , ao passo que entre os proprietários, conforme exposto acima, o índice atingiu 0,604 , e entre os condutores não passou de 0,578.

Parcela significativa dos indivíduos envolvidos no negócio de animais possuía alguma patente da guarda nacional. Este era o caso de 78 dos 500 indivíduos mais destacados nas três atividades, entre capitães, tenentes, tenentes-coronéis, coronéis, alferes, majores e comandantes. Além disto, vários deles também ocupavam cargos municipais 
de destaque, como alguns vereadores, delegados e juízes de paz. ${ }^{17}$ Nos registros, aparecem também médicos, professores, fazendeiros e até mesmo membros do clero, atestando a atratividade do negócio de animais no período.

Dentre os principais proprietários e fiadores, aparecem vários indivíduos de relevo na história da região. Entre eles, é preciso destacar a participação de João da Silva Machado, o Barão de Antonina. Envolvido desde o início do período imperial com o negócio de animais, Machado foi o responsável pela abertura da Estrada da Mata, na região serrana do Caminho das Tropas, e pela subseqüente fundação do povoado do Rio Negro, onde foi instituído o registro. Machado foi o maior proprietário de animais durante o período de Rio Negro, e também um dos principais fiadores. David dos Santos Pacheco, seu afilhado e futuro Barão dos Campos Gerais, também aparece como proprietário de destaque tanto em Rio Negro quanto em Itapetininga. O mesmo ocorre com seus irmãos Antonio e Joaquim, este último casado com Ana Marcondes de Oliveira Pacheco, filha do Barão de Tibagi e irmã do Conselheiro Jesuíno Marcondes de Oliveira e Sá (WESTPHALEN, 1995, p. 32).

Encontramos, também, vários membros de outra família de destaque da região, os Nepomuceno Prates. Aparecem nos registros os nomes do Comandante Fidelis (casado com uma neta do Barão de Antonina), do Tenente-Coronel Fidelis Jr. e do Dr. Fidencio (mais tarde presidente da Companhia Paulista de Estradas de Ferro). O Tenente-Coronel Fidelis Nepomuceno Prates Jr., além de ser o segundo maior proprietário do período de Rio Negro em número de animais, foi também o mais recorrente, fazendo passar 20 tropas entre dezembro de 1842 e dezembro de 1853. Conduziu pessoalmente a metade destas tropas, fazendo passar o restante pelas mãos de terceiros. Durante os anos de atuação da barreira de Itapetininga, o tenente-coronel perdeu lugar em importância relativa, mas ainda figura entre os principais negociantes, com 11 tropas e 6.460 animais de sua propriedade conduzidos. Fidelis freqüentemente fazia passar mais de uma tropa no mesmo dia, pelas mãos do mesmo condutor, indicando que estas tropas constituíam conjuntamente uma única transação de dimensões dilatadas. Recorreu algumas vezes a João da Silva Machado como seu fiador, além de ter prestado serviços de fiança ele próprio para tropas de dezessete proprietários diferentes. Já o Comandante Fidelis Nepomuceno Prates, que conduzira apenas duas tropas durante o período de Rio Negro, aparece como o segundo maior proprietário em número de animais na documentação de Itapetininga, conduzindo tropas de elevado tamanho - 880 animais, em média.

O principal fiador de tropas do período de Rio Negro foi o Capitão Manoel Antonio da Cunha, primeiro prefeito da vila da Lapa. Abastado comerciante da região, Manoel

17 Estas informações foram obtidas por meio de cruzamento dos nomes registrados na documentação com os Almanaques de Província de São Paulo para o ano de 1858. 
atuou como fiador entre 1831 e 1850, avalizando 173 proprietários e 160 condutores diferentes. Este padrão de dispersão das fianças entre um grande número de proprietários diferentes prevaleceu entre os fiadores de maior destaque, até mesmo entre aqueles que foram também grandes proprietários de tropas. David dos Santos Pacheco, já mencionado acima como um destacado negociante de tropas durante todo o período, afiançou tropas para 19 proprietários diferentes durante o período de atuação do registro de Rio Negro, entre eles seu irmão Antonio dos Santos Pacheco e seu sobrinho Antonio Pacheco de Carvalho. Nas passagens de Itapetininga, aparece como fiador de outras 14 tropas, privilegiando transações de grande porte de membros da própria família. Seu irmão mais novo, Joaquim Pacheco da Silva Rezende, foi o responsável pela fiança do maior número de animais que passaram por Itapetininga. Fugindo do padrão, trabalhou com apenas oito proprietários diferentes, também concentrando suas atividades nos negócios da família. Por fim, merece destaque o caso de um membro do clero, o Reverendo Joaquim de Sá Sottomaior, fiador de destaque do período de Rio Negro, responsável por mais de 11.000 animais em um curto período de aproximadamente quatro anos; o reverendo afiançou tropas para negociantes de relevo como Fidelis Nepomuceno Prates Jr. e Rafael Tobias de Aguiar. ${ }^{18}$

Muito embora as grandes transações fossem dominadas por indivíduos de elevada posição social, o negócio de animais também viabilizava outras formas de inserção. Houve casos de proprietários que se destacaram pelo número de tropas, porém não pelo número de animais, devido ao porte reduzido de suas transações. Em Rio Negro, os proprietários Generozo José de Oliveira e Antonio Ferreira Maciel conduziram pessoalmente 11 tropas cada, um número bastante elevado; entretanto, o tamanho reduzido de suas tropas - menos de 200 animais, em média - impediu-os de ocupar posição de destaque entre os proprietários com maior número de animais. Houve, também, grandes proprietários que eram eles próprios os condutores de suas tropas. José de Paula e Silva, o maior proprietário do período de Itapetininga tanto em tropas quanto em animais, além de cuidar pessoalmente da condução de seus animais, não era portador de nenhum título e não possuía conexões explícitas com as elites da região: um homem dedicado exclusivamente ao comércio de animais. O Capitão Antonio Caetano de Oliveira, principal condutor de tropas presente na documentação de Rio Negro, era também proprietário da maior parte das tropas que conduzia, porém ocasionalmente também prestava serviços a terceiros, conduzindo suas tropas. Grandes e pequenos, recorrentes e ocasionais, célebres ou desconhecidos, todos encontravam espaço no florescente negócio.

18 Rafael Tobias de Aguiar foi presidente da província de São Paulo nos períodos 1831-1835 e 1840-1841 e uma das figuras-chave da Revolução Liberal de 1842. 


\section{CONCLUSÃO}

Ao longo deste artigo, importantes aspectos relacionados ao negócio de animais de carga no período imperial foram desvendados. A compilação da série de Itapetininga e a retificação da série de Rio Negro destacam sua magnitude, realçando a dependência funcional dos centros dinâmicos da economia brasileira em relação a este sistema de abastecimento. Também lançam alguma luz sobre o volume de capitais nele empregado e sobre a importância desta atividade na geração das condições materiais de existência de uma significativa parcela da população brasileira. Outras características marcantes do negócio de animais também vieram à tona, demonstrando sua abrangência e complexidade. Embora este segmento do mercado fosse dominado por paranaenses e paulistas, também havia espaço para gaúchos, catarinenses, mineiros e vários outros. A concentração sempre marcou o negócio, porém a atuação dos grandes nunca sufocou de forma irrevogável a participação dos pequenos. Esta diversidade de formas de inserção indica que o negócio de animais não foi mero reflexo passivo dos desígnios maiores do desenvolvimento econômico brasileiro; trilhou seus próprios caminhos e imprimiu neste processo marcas profundas sobre o desenvolvimento das regiões meridionais do Brasil.

\section{REFERENNCIAS}

\section{Fontes Primárias:}

Almanak Administrativo, Mercantil e Industrial da Provincia de São Paulo para 0 ano de 1858. Organizado e redigido por Marques e Irmão. $2^{\circ}$ ano. São Paulo, 1857. Typ. de J. R. de Azevedo Marques.

Arquivo do Estado de São Paulo (AESP): Livros de Barreiras - Rio Negro e Itapetininga.

IBGE. Anuário Estatístico do Brasil, ano V (1939/40). Rio de Janeiro.

Relatórios dos presidentes da provincia de São Paulo, 1851 - 1875. Disponível em: <http:// www.crl.edu/>.

Relatórios dos presidentes da provincia do Paraná, 1854-1876. Disponível em: <http:// www.crl.edu/>. 


\section{Fontes Secundárias:}

ALMEIDA, Aluísio de. Os caminhos do sul e a feira de Sorocaba. Revista do Instituto Histórico e Geográfico Brasileiro. Rio de Janeiro, v. 187, p. 96-173, 1945.

BADDINI, Cássia Maria. Sorocaba no Império: comércio de animais e desenvolvimento urbano. 2000. Dissertação (Mestrado), FFLCH/USP. São Paulo.

BORGES, Nilsen C. O. Terra, gado e trabalho: sociedade e economia escravista em Lages, SC (1840-1865). 2005. Dissertação (Mestrado), Centro de Filosofia e Ciências Humanas, UFSC.

CALÓGERAS, João Pandiá. Transportes arcaicos no Brasil. Boletim Geográfico. Rio de Janeiro: IBGE, a. II, n. 23, p. 1670-1677, fev. 1945.

CARRARA, Ângelo Alves. Agricultura e pecuária na capitania de Minas Gerais (16741807). 1997. Tese (Doutorado), IFCS/UFRJ.

DEFFONTAINES, Pierre. As feiras de burros de Sorocaba. Boletim Geográfico. Rio de Janeiro: IBGE, a. III, n. 25, p. 42-45, 1945.

ELLIS JR., Alfredo. A economia paulista no século XVIII: o ciclo do muar, o ciclo do açúcar. São Paulo: Academia Paulista de Letras, 1979.

GOULART, José Alípio. Tropas e tropeiros na formação do Brasil. Rio de Janeiro: Conquista, 1961.

HAMEISTER, Martha Daisson. O Continente do Rio Grande de São Pedro: os homens, suas redes de relações e suas mercadorias semoventes (c.1727-1763). 2002. Dissertação (Mestrado), Instituto de Filosofia e Ciências Sociais, UFRJ. Rio de Janeiro.

KLEIN, Herbert S. A oferta de muares no Brasil central: o mercado de Sorocaba, 1825-1880. Estudos Econômicos, v. 19, n. 2, p. 347-372, maio-ago 1989.

LAVALLE, Aida Mansani. Análise quantitativa das tropas passadas no registro do Rio Negro (1830-1854). 1974. Tese (Livre Docência) - UFPR, Curitiba.

LUNA, Francisco Vidal; KLEIN, Herbert S. Slavery and the economy of São Paulo, 1750-1850. Stanford: Stanford University Press, 2003.

MOREIRA, Júlio Estrela. Caminhos das comarcas de Curitiba e Paranaguá. Curitiba: Imprensa Oficial, 1975, 3 vols.

PETRONE, Maria Tereza Schorer. O Barão de Iguape, um empresário da época da Independência. São Paulo: Cia. Editora Nacional, 1976.

PRADO JR., Caio. Formação do Brasil contemporáneo. São Paulo: Brasiliense, 2001.

RESTITUTTI, Cristiano Corte; SUPRINYAK, Carlos Eduardo. Os muares e as Minas: relações entre a demanda mineira e o mercado de animais de carga nos séculos XVIII e XIX. Anais do XII Seminário sobre a Economia Mineira. Diamantina, 2006. 
RODARTE, Mario Marcos Sampaio; GODOY, Marcelo Magalhães. Comércio e desenvolvimento urbano na Província de Minas Gerais - Primeira Metade do Século XIX. VI Congresso Brasileiro de História Econômica (ABPHE), 2005.

SUPRINYAK, Carlos Eduardo. Comércio de animais de carga no Brasil imperial: uma análise quantitativa das tropas negociadas nas províncias do Paraná e São Paulo. 2006. Dissertação (Mestrado), Unesp/FCLAr.

TESSITORE, Viviane. Fontes da riqueza pública: tributos e administração tributária na província de São Paulo (1832-1892). 1995. Dissertação (Mestrado), USP. São Paulo.

VILLELA, André. Trying times: reactions to the 1857 and 1864 crises in Brazil. Economia, v. 1, n. 2, p. 241-266, jul/dez 2000.

WESTPHALEN, Cecília Maria. O Barão dos Campos Gerais e o comércio de tropas. Curitiba: CD Editora, 1995. 